\title{
Mikołaj Marcinkowski
}

Uniwersytet Łódzki

\section{Chińsko-amerykańska rywalizacja militarna}

\section{Wprowadzenie}

Po zakończeniu zimnej wojny Stany Zjednoczone stały się mocarstwem dominującym, a system międzynarodowy zmierzał w stronę jednobiegunowości. USA zarówno pod względem politycznym, ekonomicznym, jak i militarnym były zdecydowanie potężniejsze niż jakiekolwiek inne państwo świata. Po ponad dwudziestu latach amerykańska hegemonia nie jest już taka pewna, a największym konkurentem Stanów Zjednoczonych jest Chińska Republika Ludowa.

Rosnąca potęga Chin jest jednym z najpoważniejszych wyzwań dla Waszyngtonu. Ogromny wzrost gospodarczy tego państwa ma przełożenie na jego zbrojenia i prowadzoną politykę, a te budzą coraz większe obawy USA. Stąd też kwestia Chin zajmuje coraz więcej miejsca w polityce bezpieczeństwa Stanów Zjednoczonych. Mimo ogromnej wymiany handlowej i współpracy gospodarczej, interesy obu państw silnie ze sobą kolidują. Wszystko to sprawia, iż nie można wykluczyć rywalizacji o wpływy na zachodnim Pacyfiku, a nawet militarnej konfrontacji między Pekinem a Waszyngtonem. Celem autora jest przedstawienie obecnego stanu stosunku sił między obu państwami, ich celów strategicznych oraz przeanalizowanie uwarunkowań ewentualnego konfliktu między nimi. 


\section{Siła Chin}

Wraz ze wzrostem własnej potęgi Chiny stają się coraz bardziej asertywne i aktywne na arenie międzynarodowej ${ }^{1}$. Pekin ma ambicje być jednym $\mathrm{z}$ biegunów w wielobiegunowym ładzie 2 . Oznacza to konieczność wyparcia obecności wojskowej Stanów Zjednoczonych z wód zachodniego Pacyfiku. Nie jest to zadanie łatwe, gdyż USA swoją potęgę militarną w ogromnej mierze opierają na marynarce wojennej, a rejon Azji Wschodniej jest dla Waszyngtonu wyjątkowo ważny.

Polityka Chin budzi szczególny niepokój wśród najbliższych sąsiadów. Znaczna część tych państw to sojusznicy lub bliscy partnerzy USA. Warto pamiętać, iż ChRL jest stroną w wielu sporach terytorialnych, które grożą eskalacją. Najważniejsze z nich to spór o:

- Wyspy Senkaku na Morzu Wschodniochińskim (prawo do nich zgłaszają: Chińska Republika Ludowa, Republika Chińska, Japonia);

- Wyspy Paracelskie na Morzu Południowochińskim (prawo do nich zgłaszają: Chińska Republika Ludowa, Republika Chińska, Wietnam);

- Wyspy Spratly na Morzu Południowochińskim (prawo do nich zgłaszają: Chińska Republika Ludowa, Republika Chińska, Wietnam, Filipiny, Malezja, Brunei).

O znaczeniu tych wysp decyduje ich strategiczne położenie na trasie szlaków handlowych, podwodne zasoby surowców energetycznych oraz zasobne łowiska. Ze względu na możliwość budowy na nich instalacji wojskowych i poszerzenie przez to kontroli nad pobliskimi akwenami, są nie do przecenienia także z militarnego punktu widzenia. Ponadto kontrola nad spornymi obszarami zwiększa prestiż danego państwa i podkreśla jego wiarygodność, siłę i skuteczność.

Nie można mieć wątpliwości, iż Chiny dążą do przejęcia nad tymi obszarami całkowitej kontroli. Co ważne, chińska polityka staje się coraz bardziej agresywna i jest realizowana metodą faktów dokonanych i prowokacji. Już w 1992 roku parlament ChRL przyjął ustawę o morzu i uznał sporne archipelagi na Morzu Południowochińskim za terytorium Chin 3 . W 2014 roku Pekin umieścił na spornych wodach Morza Południowochińskiego platformę wiertniczą, co spotkało się ze sprzeciwem Hanoi. Ponadto Chińczycy

$1 \quad$ M. Pietrasiak, D. Mierzejewski, Między wzrastaniem a harmonia - uwagi o chińskiej polityce zagranicznej, [w:] Chiny w stosunkach międzynarodowych, M. Pietrasiak, D. Mierzejewski (red.), Łódź 2012, s. 8-9.

2 A. Popis-Benesz, Stosunki USA-Chiny w pierwszej dekadzie XXI wieku, [w:] Chińska polityka zagraniczna i jej uwarunkowania, J. Marszałek-Kawa (red.), Toruń 2008, s. 108.

3 E. Haliżak, Polityka i strategia Chin w kształtowaniu międzynarodowego bezpieczeństwa, seria: „Żurawia Papers”, z. 10, Warszawa 2008, s. 71-72. 
rozmieszczają na spornych wyspach instalacje wojskowe, a w razie potrzeby powiększają wyspy lub tworzą nowe. Dobrym przykładem tego jest Woody Island, na której Chińczycy wybudowali lotnisko, port wraz z nabrzeżem, stację radiolokacyjną oraz umieścili dwie baterie rakiet HQ $9 \mathrm{z}$ radarowymi systemami kierowania ogniem ${ }^{4}$. Wyspa ta została także znacznie powiększona. Przykładów tego typu działań jest znacznie więcej.

Dzięki temu Chiny zwiększają swoje możliwości rozpoznawcze i projekcji siły. Kontrola nad Morzem Południowochińskim, przez które biegną jedne z najważniejszych szlaków handlowych świata, jest kluczowa dla każdego państwa, które ma ambicje być mocarstwem na Pacyfiku.

Pekin stara się także podkreślić swoje stanowisko $\mathrm{w}$ sporze $\mathrm{z}$ Japonią. W 2013 roku Chiny stworzyły Strefę Identyfikacji Obrony Powietrznej Morza Wschodniochińskiego (East China Sea Air Defense Identification System - ADIZ), która obejmuje m.in. wyspy Senkaku. Tym sposobem ChRL stara się wyprzeć japońskie i amerykańskie lotnictwo znad spornych obszarów, co stanowi kolejny krok w drodze do chińskiej dominacji w regionie.

Odrębny problem stanowi kwestia Tajwanu. Pekin od lat dąży do przejęcia kontroli nad wyspą, także przy użyciu środków militarnych. W 2005 roku parlament Chin przyjął ustawę antysecesyjną, w której jednoznacznie sprzeciwiono się próbom ogłoszenia niepodległości przez Tajpej. Zagrożono, że jeśli inne metody zawiodą, to Chińska Republika Ludowa odwoła się do niepokojowych środków w celu utrzymania integralności i suwerenności państwa ${ }^{5}$.

Ponadto Chiny budują infrastrukturę morską i wojskową wzdłuż szlaków handlowych na Oceanie Indyjskim. Rozbudowywany „sznur pereł” stanowi istotną oznakę ambicji i rosnącej pozycji Chin. Państwo Środka poczyniło ogromne inwestycje m.in. w Pakistanie, równoważąc przy tym, a nawet wypierając z regionu wpływy Indii i Stanów Zjednoczonych ${ }^{6}$.

Wpływ na politykę Chin ma ogromny wzrost gospodarczy. Gospodarka ChRL rośnie od ponad 30 lat w tempie około 10\% rocznie. Wzrost gospodarczy i znaczne polepszenie sytuacji ekonomicznej kraju przekłada się na istotne zwiększenie budżetu obronnego i wydatków na zbrojenia.

4 A. Blicharz, Chiny wzmocnity sporne wyspy na Morzu Południowochińskim, „Nowa Strategia” 18.02.2016, http://www.nowastrategia.org.pl/chiny-wzmocnily-sporne -wyspy-na-morzu-poludniowochinskim/ (dostęp: 01.05.2016).

5 E. Haliżak, op. cit., s. 81.

6 V. Marantidou, Revisiting China's 'String of Pearls' Strategy: Places 'with Chinese Characteristics' and their Security Implications, „Issues \& Insights” 2014, nr 7, s. 3-29, https:// csis-prod.s3.amazonaws.com/s3fs-public/legacy_files/files/publication/140624_issuesinsights_vol14no7.pdf (dostęp: 03.05.2016). 


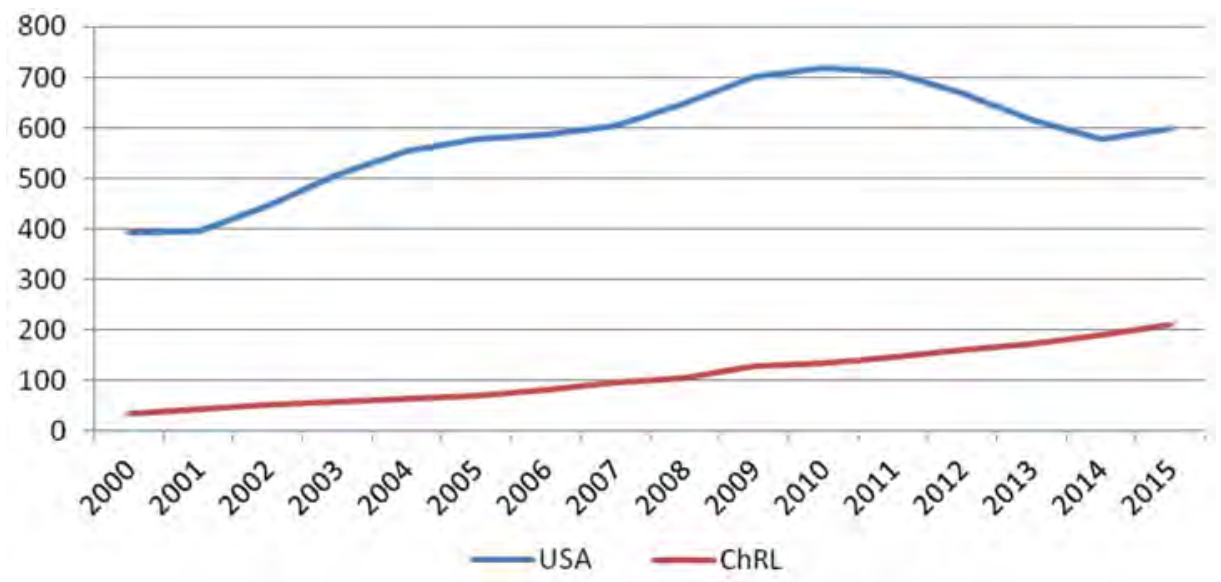

Wykres 1. Budżety obronne USA i ChRL (wydatki w miliardach dolorów)

Źródło: opracowanie własne na podstawie The SIPRI Military Expenditure Database 2015.

Chiny ukrywają znaczą część wydatków wojskowych, niemniej jednak szacuje się, że w 2016 roku wydadzą na ten cel około 200 mld dolarów. Budżet obronny ChRL rośnie średnio 11\% rocznie, co oznacza, iż w latach 1996-2015 wzrósł ponad sześciokrotnie ${ }^{7}$. Obecnie Chiny są drugim, po USA, państwem na świecie pod względem wydatków na zbrojenia. Co ważne, różnica w wysokości budżetów obronnych USA i ChRL zmniejsza się i wszystko wskazuje na to, iż proces ten będzie trwał. O ile w 2000 roku Stany Zjednoczone wydawały w tej dziedzinie ponad 10 razy więcej niż Chiny, to obecnie jest to około 3 razy więcej. Wzrost nakładów na zbrojenia pozwala na znaczną modernizację sił zbrojnych i pozyskiwanie nowych zdolności militarnych. ChRL rozwija projekty nowych czołgów, samolotów i innych platform bojowych ${ }^{8}$. Nowe typy czołgów 98 i 99 stanowią obecnie około $10 \%$ wszystkich czołgów $\mathrm{ChRL}^{9}$. O ile w 2003 roku w chińskiej flocie jedynie 14\% niszczycieli i 24\% fregat mogło być uznane za nowoczesne, to w 2015 roku było to odpowiednio $65 \%$ niszczycieli i $69 \%$ fregat $^{10}$. W 2012 roku do służby wszedł pierwszy chiński lotniskowiec - Liaoning. Chiny posiadają także swój program myśliwca 5 generacji ${ }^{11}$.

7 E. Heginbotham, The U.S.-China Military Scorecard Forces, Geography, and the Evolving Balance of Power, 1996-2017, Santa Monica 2015, s. 25-26, http://www.rand.org/content/ dam/rand/pubs/research_reports/RR300/RR392/RAND_RR392.pdf(dostęp: 09.07.2017).

8 Ibidem, s. 25-27.

$9 \quad$ Ibidem, s. 33.

10 Ibidem, s. 30.

11 R. S. Chhatwal, Stealth fighter: challanges for Indian Air Forces, Centre for Air Power Studies 2015, s. 1-3, http://capsindia.org/files/documents/CAPS_Infocus_RS_12.pdf (dostęp: 03.05.2016). 
Chiny już w latach 90. XX wieku zdały sobie sprawę, iż ich siły zbrojne nie są dostosowane do wymagań współczesnych konfliktów zbrojnych. Kluczowym wydarzeniem była wojna w Zatoce Perskiej, która potwierdziła amerykańską dominację militarną. Amerykańska RMA (Revolution in Military Affairs) sprawiła, iż nie można było już dłużej zastępować jakości ilością. Pekin wyciągnął wnioski i rozpoczął modernizację. O ile w 1985 roku armia ChRL liczyła 4,1 mln żołnierzy, to w 1995 roku było to 2,9 mln, a w 2010 roku $-2,2 \mathrm{mln}^{12}$. Idea wojny ludowej, opartej na masowej armii zaczęła być zastępowana przez koncepcję wojny lokalnej w warunkach informatyzacji, poprzez zwiększenie stopnia nasycenia sił zbrojnych nowoczesnym uzbrojeniem i wdrożeniem odpowiednich doktryn wojskowych ${ }^{13}$.

Dlatego też Chiny rozwinęly znacznie swój system C4ISR (Command, Control, Communications, Computing, Intelligence, Reconnaissance, Surveillance) i uzyskały istotną zdolność zakłócania systemów C4ISR przeciwnika ${ }^{14}$. ChRL posiada co najmniej jeden radar pozahoryzontalny (OTH radar), własny system nawigacji satelitarnej Beidou oraz system łączności satelitarnej ${ }^{15}$.

Ogromy postęp państwo to poczyniło także w sferze wojsk rakietowych oraz broni jądrowej ${ }^{16}$. Chiny posiadają coraz więcej głowic i coraz lepsze środki przenoszenia. Istotnym efektem rozwoju technologii rakietowych jest uzyskanie przez Chiny zdolności niszczenia satelitów. Pekin dowiódł skuteczności własnej broni antysatelitarnej w 2007 roku, kiedy zestrzelił swojego satelitę umieszczonego na orbicie okołoziemskiej.

Bez wątpienia dla Chin priorytetem jest rozwój zdolności Anti-Access/ Area Denial. Pekin od lat rozwija strategię A2/AD, która polega na uniemożliwieniu przeciwnikowi dotarcia na teatr działań, a jeżeli to się nie uda, to utrudnianie mu poruszania się po nim oraz zniszczenie go ${ }^{17}$. Dzięki temu zagrożenie zostaje odsunięte od terytorium na bezpieczną odległość ${ }^{18}$. Główną

12 R. Kwieciński, Nowa strategia globalna Chińskiej Republiki Ludowej? Wyzwania i dylematy bezpieczeństwa narodowego Chin, [w:] Globalna potega Chin. Czynniki i perspektywy, J. Marszałek-Kawa (red.), Toruń 2014, s. 74.

13 Ibidem, s. 84.

14 E. Heginbotham, op. cit., s. 32.

15 Ibidem.

16 Ibidem, s. 28.

17 Air-Sea Battle. Service Collaboration to Address Anti-Access \& Area Denial Challenges, Air-Sea Battle Office 2013, s. 2-3, http://archive.defense.gov/pubs/ASB-ConceptImplementation-Summary-May-2013.pdf (dostęp: 03.05.2016).

18 R. Czulda, Rakiety przeciwlotnicze blokuja dostęp do spornych wysp. Chińska strategia $w$ praktyce, „Defence24”, 17.02.2016, http://www.defence24.pl/309703, rakiety- 
siłą chińskiej strategii A2/AD są wojska rakietowe. Mają one do dyspozycji coraz więcej, coraz bardziej nowoczesnych pocisków balistycznych i rakiet manewrujących ${ }^{19}$. W zasięgu znacznej ilości chińskich wyrzutni są sporne wyspy na Morzu Południowochińskim oraz na Morzu Wschodniochińskim, a ponadto Tajwan, Korea Południowa, Japonia, Filipiny czy nawet Guam ${ }^{20}$. Istotnym uzupełnieniem chińskich zdolności w ramach strategii A2/AD są siły powietrzne, marynarka wojenna oraz zdolności zakłócania systemu C4ISR przeciwnika i działania w cyberprzestrzeni.

Nie można mieć wątpliwości, że Chiny dokonały ogromnego postępu i stały się najpoważniejszym konkurentem dla Stanów Zjednoczonych w rywalizacji o kontrolę i wpływy w Azji Wschodniej i na Pacyfiku. Zdolności militarne uzyskane przez Chińską Republikę Ludową muszą niepokoić amerykańskich decydentów. Szczególnie rozwój zdolności w zakresie A2/AD stanowi istotną przeszkodę w realizacji amerykańskich celów w tym regionie. Jeśli jednak Chiny chcą odgrywać większą rolę i bronić swoich interesów, potrzebują rozwinąć zdolności ofensywne. Szczególne zadanie ma marynarka wojenna, która musi zabezpieczyć główne szlaki handlowe, przez które Chiny eksportują wyprodukowane towary i importują surówce energetyczne. Dlatego też Pekin planuje wprowadzić do służby kolejne lotniskowce i znacznie zwiększać swoje zdolności militarne, by móc operować na dwóch oceanach. Wszystko to oznacza rzucenie wyzwania niekwestowanemu do tej pory hegemonowi morskiemu, jakim są Stany Zjednoczone.

\section{Polityka USA wobec chińskiego wzrostu}

Amerykanie rozumieją, że jeżeli chcą zabezpieczyć swoje interesy, to muszą zachować światową dominację i bez wątpienia Stany Zjednoczone zamierzają bronić swojej pozycji. Dlatego też tak dużo uwagi poświęcają Chinom. Waszyngton za szczególnie istotne uważa zapewnienie wolności żeglugi na Morzu Południowochińskim, przejrzystości polityki zbrojeniowej oraz niestosowanie środków militarnych ${ }^{21}$. Widoczna jest zatem sprzeczność interesów i celów obu państw. Już w 2001 roku prezydent George W. Bush powiedział, że między USA a ChRL nie ma strategicznego partnerstwa, istnieje zaś

przeciwlotnicze-blokuja-dostep-do-spornych-wysp-chinska-strategia-w-praktyce (dostęp: 02.05.2016).

19 E. Heginbotham, op. cit., s. 48.

20 Ibidem.

21 J. Tomaszewski, Zmiany w polityce bezpieczeństwa USA, „Bezpieczeństwo Narodowe" 2012, nr 23-24, s. 93. 
strategiczna konkurencja ${ }^{22}$. Choć Barack Obama zmienił retorykę, to istota amerykańskiej polityki pozostała ta sama.

W stosunkach z Pekinem Waszyngton stosuje mix polityki zaangażowania (engagement), odstraszania (deterrence) i zapewnienia o chęci współpracy (reassurance) ${ }^{23}$. Niemniej jednak na polu militarnym Stany Zjednoczone starają się „okrążyć” i powstrzymywać Chiny (China containment policy). Strategia ta zakłada zwiększenie obecności militarnej w regionie oraz rozbudowę sieci sojuszy.

W 2009 roku Stany Zjednoczone ogłosiły reorientację swojej polityki w kierunku Azji i Pacyfiku. Pivot to Asia spowodowany jest rosnącym znaczeniem ekonomicznym, politycznym i militarnym tego regionu. Nie można mieć jednak wątpliwości, iż głównym powodem „Zwrotu” jest wzrost znaczenia ChRL i zbrojenia tego państwa. Obok niestabilnej sytuacji na Półwyspie Koreańskim, to polityka Chin jest największym wzywaniem dla USA w regionie. Cele i intencje Pekinu pozostają niejasne dla Waszyngtonu, a metody coraz bardziej niepokojące.

W październiku 2011 roku Hilary Clinton w artykule „America’s Pacific Century" przedstawiła sześć głównych kierunków polityki USA w regionie: wzmocnienie sojuszy dwustronnych, rozwój relacji ze wschodzącymi mocarstwami (w tym z Chinami), współpraca z regionalnymi organizacjami międzynarodowymi, zwiększenie wymiany handlowej i inwestycji, zwiększenie obecności wojskowej, a także wspieranie demokracji i praw człowieka ${ }^{24}$.

Celem Stanów Zjednoczonych jest pozostanie dominującym mocarstwem na Pacyfiku ${ }^{25}$. Dlatego też Waszyngton pogłębia współpracę z sojusznikami i partnerami oraz zwiększa siły i środki w tym regionie ${ }^{26}$. Obecność

22 M. Huashou, Retrospekcje i perspektywy rozwoju stosunków pomiędzy ChRL a USA, [w:] Chiny supermocarstwem XXI wieku? Rozważania na temat polityki i gospodarki Państwa Środka, J. Marszałek-Kawa (red.), Toruń 2010, s. 53.

23 M. Green, K. Hicks, M. Cancian, Asia-Pacific Rebalance 2025. Capabilities, Presence, and Partnerships. An Independent Review of U.S. Defense Strategy in the Asia-Pacific, Center for Strategic \& International Studies, Washington 2016, s. 10, https://csis -prod.s3.amazonaws.com/s3fs-public/legacy_files/files/publication/160119_Green_ AsiaPacificRebalance2025_Web_0.pdf (dostęp: 03.05.2016).

24 H. Clinton, America’s Pacific Century, „Foreign Policy”, 11.10.2011, http://foreignpolicy.com/2011/10/11/americas-pacific-century/ (dostęp: 02.05.2016).

25 National Security Strategy, Washington 2015, s. 24, https://obamawhitehouse.archives. gov/sites/default/files/docs/2015_national_security_strategy.pdf (dostęp: 03.05.2016).

26 K. Campbell, B. Andrews, Explaining the US 'Pivot' to Asia, „Americas” 2013, nr 1, s. 2, https://www.coursehero.com/file/21690284/Explaining-the-US-Pivot-to-Asiapdf/ (dostęp: 03.05.2016). 
militarna USA w tej części świata ma być gwarantem bezpieczeństwa i po$\mathrm{koju}^{27}$. W Strategii Bezpieczeństwa Narodowego USA spory terytorialne na Morzu Wschodniochińskim oraz Morzu Południowochińskim zostały uznane za jedne $\mathrm{z}$ najgroźniejszych wyzwań dla bezpieczeństwa ${ }^{28}$. Niestabilna sytuacja i możliwość eskalacji konfliktów sprawiają, że Waszyngton uważa swoje interesy w regionie za zagrożone ${ }^{29}$. Nie brakuje także bezpośrednich sporów między Stanami Zjednoczonymi a Chinami.

Na Morzu Południowochińskim Stany Zjednoczone prowadzą operacje swobodnej żeglugi (Freedom of Navigation Operation - FONOP), polegające na patrolowaniu tego akwenu przez okręty marynarki wojennej USA. W trakcie tych działań Amerykanie wielokrotnie przepływali w odległość mniejszej niż 12 mil morskich od spornych wysp, czyli po wodach, które Chiny uważają za swoje wody terytorialne. Mimo protestów Pekinu, Waszyngton oświadczył, iż nie uznaje roszczeń terytorialnych i dalej zamierza bronić swobody żeglugi ${ }^{30}$. Ponadto Stany Zjednoczone stanowczo sprzeciwiają się militaryzacji spornych wysp przez ChRL.

Kluczowym problemem w stosunkach Waszyngtonu $\mathrm{z}$ Pekinem pozostaje Tajwan. Choć Stany Zjednoczone oficjalnie uznają zasadę ,jednych Chin”, to $\mathrm{w}$ rzeczywistości utrzymują bliskie stosunki z Tajpej i wspierają Republikę Chińską. Stany Zjednoczone od wielu lat sprzedają broń Tajwanowi. W 2011 roku wartość sprzedanego przez USA uzbrojenia do tego kraju wynosiła 5,3 mld dolarów, a w grudniu 2015 roku zatwierdzono z kolei transakcję na 1,8 mld dolarów ${ }^{31}$. Tego typu działania spotykają się ze zdecydowanym sprzeciwem władz w Pekinie. Dla Tajpej utrzymywanie dobrze wyposażonej i sprawnej armii wydaje się być jednak najlepszym zabezpieczeniem przed siłowym włączeniem do ChRL. Choć USA nie gwarantują Tajwanowi pomocy w wypadu konfliktu, to $\mathrm{w}$ ich interesie jest zachowanie niepodległości przez to państwo, gdyż ich pozycja w Azji Wschodniej i na Pacyfiku w dużej mierze zależy od specyfiki relacji z państwami regionu.

27 Quadrennial Defense Review, Washington 2014, s. 9, http://archive.defense.gov/ pubs/2014_Quadrennial_Defense_Review.pdf (dostęp: 03.05.2016).

28 National Security Strategy, s. 10.

29 Defense Strategic Guidance, Washington 2012, s. 2, http://archive.defense.gov/news/ Defense_Strategic_Guidance.pdf (dostęp: 03.05.2016).

30 A Freedom of Navigation Primer for the Spratly Island, „Asia Maritime Transparency Initiative”, 02.11.2015, http://amti.csis.org/fonops-primer/ (dostęp: 02.03.2016).

31 D. Cameron, U.S. Clears Weapons Sale to Taiwan, „The Wall Street Journal”, 16.12.2015, http://www.wsj.com/articles/u-s-clears-weapons-sale-to-taiwan-1450291541 (dostęp: 03.05.2016). 
Do najważniejszych sojuszników USA w tej części świata zaliczyć należy: Japonię, Koreę Południową, Australię, Tajlandię oraz Filipiny ${ }^{32}$. Waszyngton podejmuje działania na rzecz pogłębienia współpracy z tymi państwami. Rozwija także partnerstwo z Indiami, Nową Zelandią, Singapurem, Indonezją, Malezją, Wietnamem oraz Bangladeszem ${ }^{33}$. Ze względu na swój potencjał, szczególne miejsce zajmują Indie. Oba państwa od lat rozwijają relacje ekonomiczne i militarne ${ }^{34}$. W 2012 roku uruchomiły współpracę na podstawie Defense Technology and Trade Initiative, zaś w 2015 roku zawarły 10-letnie porozumienie o współpracy w dziedzinie obronności ${ }^{35}$. Dla USA Indie są bezcennym partnerem, który mógłby przynajmniej częściowo równoważyć rosnącą pozycję Chin. Waszyngton od dłuższego czasu stara się stworzyć wielostronne forum współpracy w dziedzinie bezpieczeństwa między USA, Japonią, Australia i Indiami. Bez wątpliwości plan zawiązania takiego sojuszu ma wyraźnie antychiński charakter, ale póki co jest daleki od realizacji.

W państwach sojuszniczych USA regionu Azji i Pacyfiku stacjonuje ponad 80 tys. amerykańskich żołnierzy, z czego około 40 tys. w Japonii, a około 30 tys. w Korei Południowej ${ }^{36}$. Dla porównania, w rejonie Zatoki Perskiej jest obecnie ok. 35 tys. wojskowych USA ${ }^{37}$. Niemniej jednak ewidentnie widać niedostatek amerykańskich sił w okolicach Morza Południowochińskiego. Waszyngton stara się to zmienić, stąd też porozumienie z Australią o obecności żołnierzy USA, czy też współpraca z Wietnamem. Coraz bardziej agresywna polityka Chin sprawia, iż państwa regionu same starają się pogłębiać współpracę ze Stanami Zjednoczonymi i zwiększyć tym samym swoje bezpieczeństwo ${ }^{38}$.

32 J. Tomaszewski, Traktatowi sojusznicy USA w regionie Azji i Pacyfiku, „Bezpieczeństwo Narodowe" 2013, nr 25, s. 23.

33 The National Military Strategy of the United States of America 2015, s. 9, http://www. jcs.mil/Portals/36/Documents/Publications/2015_National_Military_Strategy.pdf (dostęp: 03.05.2016).

34 D. Zbytek, Azjatycka szachownica. Ameryka, Chiny, Indie, Pakistan, „Sprawy Polityczne", Warszawa 2008, s. 37.

35 L. Qadir, The United States and India Sign a 10-Year Defense Agreement and Set the Stage for Increased Defense Cooperation, „Global Public Policy and Government Affairs”, 11.06.2015, https://www.globalpolicywatch.com/2015/06/the-united-states-and-india -sign-a-10-year-defense-agreement-and-set-the-stage-for-increased-defense-cooperation/ (dostęp: 03.05.2016).

36 M. Green, K. Hicks, M. Cancian, op. cit., s. 36-114.

37 Quadrennial Defense Review, s. 34-35.

38 M. Green, Rethinking U.S. Military Presence in Asia and the Pacific, [w:] Global Forecast 2012, C. Cohen, J. Gabel (red.), Washington 2012, s. 20, https://csis-prod.s3.amazonaws. com/s3fs-public/legacy_files/files/publication/120413_gf_green.pdf(dostęp: 03.05.2016). 
Choć siły i środki USA są ogromne, nie oznacza to, iż są wystarczające do przeciwstawianie się wszelkim wyzwaniom i zagrożeniom $w$ każdym regionie świata. Waszyngton musi skupiać się na priorytetach ${ }^{39}$. Istotne ograniczenia możliwości militarnych są spowodowane m.in. cięciami na wydatki obronne w ostatnich latach. Ponieważ priorytetem jest Azja i Pacyfik, to obecność militarna USA w tym regionie systematycznie się zwiększa. Zgodnie z danymi "Quadrennial Defense Review", do 2020 roku 60\% sił marynarki wojennej Stanów Zjednoczonych będzie stacjonowało na Pacyfiku ${ }^{40}$. Odpowiedzialne za ten region dowództwo USPACOM (United States Pacific Command) jest największym ze wszystkich połączonych dowództw (Unified Combatant Command) Sił Zbrojnych Stanów Zjednoczonych. Dysponuje ponad 360 tysiącami żołnierzy, około 2 tysiącami samolotów i około 200 okrętami.

W USA dostrzeżono potrzebę modernizacji sił zbrojnych do nowych wyzwań takich jak wojna hybrydowa, zagrożenia asymetryczne, konflikt z państwami posiadającymi broń masowego rażenia, czy też stosującymi strategię Anti-Access/Area Denial ${ }^{41}$. Odpowiedzią USA na rozwój zdolności A2/AD w ChRL jest koncepcja bitwy powietrzno-morskiej (Air-Sea Battle), która ma umożliwić operowanie $\mathrm{w}$ strefach $\mathrm{A} 2 / \mathrm{AD}^{42}$. Choć Waszyngton unika określania bitwy powietrzno-morskiej mianem doktryny, to faktycznie jest to odpowiednik doktryny bitwy powietrzno-lądowej z okresu zimnej wojny. Pokazuje to jak poważnie traktowane jest chińskie zagrożenie.

Bitwa powietrzno-morska zakłada stworzenie sieciocentrycznego pola walki, integrację sił własnych, a następnie przeprowadzenie głębokich uderzeń, których celem jest zakłócenie systemów C4ISR przeciwnika, zniszczenie jego zdolności A2/AD, a ostatecznie jego pokonanie (NIA/D3 - networked, integrated forces capable of attack-in-depth to disrupt, destroy and defeat adversary forces $)^{43}$. Taka strategia jest przeznaczona do działania $\mathrm{w}$ środowisku, gdzie przeciwnik może wykorzystać pociski kierowane i balistyczne, zaawansowane systemy obrony powietrznej, środki walki elektronicznej oraz gdzie jest zdolny zniszczyć okręty amerykańskiej marynarki wojennej ${ }^{44}$. Jest zatem bezpośrednio dostosowana do wymagań zachodniego Pacyfiku.

Jedną z najbardziej niepokojących rzeczy dla amerykańskich wojskowych jest rozwój chińskich zdolności w sferze zwalczania satelitów. Biorąc pod

\footnotetext{
Quadrennial Defense Review, s. 53.

Ibidem, s. 34-35.

Ibidem, s. 6.

Defense Strategic Guidance, s. 4-5.

Air-Sea Battle, op. cit., s. 5-7.

Ibidem, s. 8-9.
} 
uwagę rosnące uzależnienie sił zbrojnych USA od łączności satelitarnej, zwiadu kosmicznego czy systemów naprowadzania i pozycjonowania, to stanowi ono poważne zagrożenie. Rozwój technologii rakietowych ChRL jest szczegółowo analizowany przez amerykańskich ekspertów. Jak podają autorzy „Ballistic Missile Defense Posture Review”, obok Rosji, to właśnie Chiny mają zdolność przeprowadzenia zmasowanego ataku rakietowego na terytorium USA ${ }^{45}$.

Warto pamiętać, iż dla USA Chiny są kluczowym partnerem gospodarczym. Oba państwa są bardzo mocno powiązane ekonomicznie. Niemniej jednak chińskie zbrojenia i polityka regionalna budzą niepokój w Waszyngtonie. Stany Zjednoczone chcą rozwijać współpracę gospodarczą z Pekinem, lecz jednocześnie chcą, by Chiny prowadziły bardziej transparentną i pokojową politykę ${ }^{46}$.

\section{Konflikt}

Prawdopodobieństwo otwartego konfliktu między Stanami Zjednoczonymi a Chinami jest małe. Niemniej jednak nie można całkowicie wykluczyć takiego scenariusza. Zarówno działania Chin, jak i USA nakręcają spiralę zbrojeń i obniżają poziom wzajemnego zaufania. Oba kraje stoją w obliczu dylematu bezpieczeństwa ${ }^{47}$. Wzrost znaczenia Chin, nietransparentna polityka tego państwa, zbrojenia, ukrywanie części budżetu obronnego i działania w regionie potęgują obawy Waszyngtonu. Bierna reakcja USA byłaby dowodem na ich słabnącą pozycję i podważyłaby ich mocarstwowy status ${ }^{48}$. Waszyngton musi upewniać swoich sojuszników, że jest w stanie zagwarantować im bezpieczeństwo. Do tego konieczna jest zdolność odstraszania Chin ${ }^{49}$. W oficjalnych dokumentach Stany Zjednoczone zastrzegają sobie prawo do jednostronnego użycia siły, jeśli ich interesy lub bezpieczeństwo sojuszników będą zagrożone ${ }^{50}$. Zgodnie z „Nuclear Posture Review” z 2010 roku, Waszyngton dopuszcza na-

45 Ballistic Missile Defense Posture Review, Washington 2010, s. 4, http://archive.defense.gov/bmdr/docs/BMDR\%20as\%20of\%2026JAN10\%200630_for\%20web.pdf (dostęp: 03.05.2016).

46 M. Kostrzewa, Strategic Reassurance. Nowa koncepcja czy słabość polityki USA wobec Chin?, „Kwartalnik Kolegium Ekonomiczno-Społecznego. Studia i Prace”, Warszawa 2011, s. 15.

47 B. Glaser, Pivot to Asia: Prepare for Unintended Consequences, [w:] Global Forecast 2012, s. 24.

48 Ibidem, s. 23.

49 Ibidem, s. 24.

50 National Security Strategy, s. 8. 
wet użycie broni jądrowej ${ }^{51}$. Z kolei zwiększanie zaangażowania USA w Azji i na Pacyfiku, rozbudowa baz, tworzenie sieci sojuszy i silna obecność wojskowa utrudniają realizację celów ChRL i dlatego też budzą niepokój w Pekinie ${ }^{52}$.

Zarówno Stanom Zjednoczonym, jak i Chinom zależy na kontrolowaniu łańcuchów wysp na Pacyfiku. Pierwszy z nich biegnie od Japonii przez wyspę Kiusiu i archipelag Riukiu, dalej przez Tajwan, Filipiny i Malezję. Drugi łańcuch wysp zaczyna się od wschodnich wybrzeży Japonii i biegnie przez Guam, aż po Papuę-Nową Gwineę. Kontrola tych obszarów jest niezbędna do dominacji na zachodnim Pacyfiku i może być elementem spornym między oboma państwami.

Do konfliktu między Stanami Zjednoczonymi a Chinami mogłaby doprowadzić chociażby próba siłowego rozwiązania problemu Tajwanu. Nie można wykluczyć, iż Pekin zdecyduje się na takie rozwiązanie. Szczególnie prawdopodobne mogłoby się to stać, gdyby Tajpej zdecydowało się na ogłoszenie niepodległości. Kryzys w Cieśnienie Tajwańskiej z 1996 roku pokazał, że zarówno ChRL, jak i USA są zdeterminowane, by rozwiązać spór zgodnie z własnym interesem. Jednakże w ciągu dwudziestu lat sytuacja znacznie się zmieniła. Amerykanie zaniepokojeni są rosnącą dysproporcją sił między ChRL a Republiką Chińską ${ }^{53}$. Chińska Republika Ludowa wzmocniła swoje siły zbrojne i przewaga USA w regionie nie jest już taka duża. Ponadto analizy wskazują, iż czas działa na korzyść Pekinu i z roku na rok wyniki symulacji wojny o Tajwan stają się coraz bardziej niepokojące dla strony amerykańskiej54. Taki stan rzeczy może zachęcać Pekin do bardziej zdecydowanych działań.

Również sytuacja na Morzu Południowochińskim stwarza ryzyko konfliktu angażującego oba państwa. Militaryzacja tego obszaru i przejmowanie kontroli nad strategicznie ważnym akwenem godzi w interesy USA. Z kolei amerykańskie operacje typu FONOP, w trakcie których, zdaniem Pekinu, okręty US Navy naruszają wody terytorialne Chin, mogą spotkać się ze stanowczą odpowiedzią. Szef operacji morskich marynarki wojennej ChRL Wu Shengli stwierdził, że amerykańska aktywność w regionie może doprowadzić do wojny między oboma państwami ${ }^{55}$. Jeśli nie zamierzone działania, to

51 Nuclear Posture Review Report, Washington 2010, s. 16-17, https://www.defense.gov/ Portals/1/features/defenseReviews/NPR/2010_Nuclear_Posture_Review_Report. pdf (dostęp: 03.05.2016).

52 B. Glaser, op. cit., s. 22.

53 Ballistic Missile Defense Posture Review, s. 7.

54 E. Heginbotham, op. cit., s. 318.

55 Chiny oficjalnie strasza USA wojną, „Niezależna”, 31.10.2015, http://niezalezna. pl/72489-chiny-oficjalnie-strasza-usa-wojna (dostęp: 04.05.2016). 
nawet incydent mógłby doprowadzić do eskalacji, gdyby żadna ze stron nie chciała ustąpić.

Ryzyko konfliktu jest także związane ze sporem o wyspy Senkaku. Japonia jest bez wątpienia jednym $z$ najważniejszych sojuszników USA i państwo to posiada gwarancje bezpieczeństwa ze strony Stanów Zjednoczonych. W 2014 roku Barack Obama jednoznacznie oświadczył „Nasze zobowiązanie do pomocy militarnej dla Japonii odnosi się do wszystkich terytoriów przez nią administrowanych, w tym do wysp Senkaku" ${ }^{\text {" }}$. Amerykanie nie uznali ustanowionej przez ChRL Strefy Identyfikacji Obrony Powietrznej i niemal natychmiast po jej utworzeniu przeleciały przez nią dwa bombowce B-52 ${ }^{57}$. Trudno przewidzieć, co by się stało, gdyby Pekin zdecydował się przechwycić, zmusić do lądowania lub zestrzelić amerykański samolot. Incydenty tego typu miały już miejsce między oboma państwami. W 2001 roku doszło do zderzenia samolotu rozpoznawczego EP-3 należącego do Stanów Zjednoczonych $\mathrm{z}$ chińskim myśliwcem J-8. W jego wyniku maszyna należąca do ChRL runęła do morza, a jej pilot poniósł śmierć. EP-3 został uszkodzony i awaryjnie musiał lądować na terytorium Chin.

Bez wątpienia największym atutem Pekinu jest strategia A2/AD, która pozwala trzymać siły przeciwnika na bezpieczny dystans. Rozwój wojsk rakietowych ChRL sprawił, iż wszystkie najważniejsze bazy i lotniska USA w regionie, to jest: Kadena, Futenma, Kunsan, Osan, Iwakuni, Yokota, Misawa, Andersenson są zagrożone atakiem rakietowym ${ }^{58}$. Amerykańskie okręty operujące na wodach zachodniego Pacyfiku są w zasięgu chińskich pocisków balistycznych i rakiet manewrujących. Na korzyść Chin działa asymetria geograficzna. Ewentualny teatr działań znajdowałby się zdecydowanie bliżej terytorium ChRL. Niemniej jednak chińska przewaga znacznie maleje wraz ze wzrostem odległości od kontynentu ${ }^{59}$. Nie można mieć wątpliwości, iż w przypadku starcia głównym celem Chin będzie system C4ISR, lotniskowce oraz bazy USA w regionie. Zmusza to Stany Zjednoczone do zmiany dyslokacji samolotów i okrętów w rejony niezagrożone atakiem. Ma to oczywiście ogromne znaczenie. W wypadku nagłego wybuchu konfliktu w Cieśninie Taj-

56 M. Zawadzki, Prezydent USA objeżḋa Azję. Obama zaczął od uspokajania Japonii, wyborcza.pl, 25.04.2014, http://wyborcza.pl/1,76842,15852929,Prezydent_USA_objezdza_Azje_Obama_zaczal_od_uspokajania.html\#ixzz4862jfKtc (dostęp: 04.05.2016).

57 Seul odpowiada Chinom. Rozszerza strefe obrony powietrznej, tvn24.pl, 29.11.2013, http://www.tvn24.pl/wiadomosci-ze-swiata,2/seul-odpowiada-chinom-rozszerza -strefe-obrony-powietrznej,375577.html (dostęp: 04.05.2016).

58 E. Heginbotham, op. cit., s. 55.

59 Ibidem, s. 21. 
wańskiej lotniskowiec wraz z grupą uderzeniową mógłby dotrzeć z Japonii na teatr działań w ciągu dwóch dni, okręty z Guam potrzebowałyby od dwóch do trzech dni, z Pearl Harbor od siedmiu do dziewięciu dni, zaś z San Diego od dziesięciu do dwunastu dni ${ }^{60}$.

Przez ostatnie lata USA dostosowywały swoją strategię i siły zbrojne do wyzwań globalnych, Chiny natomiast poświęcały niemal całą swą uwagę na region Azji i Pacyfiku ${ }^{61}$. Nie oznacza to jednak, iż Stany Zjednoczone są na przegranej pozycji. Zwrot w kierunku Azji i zwiększanie obecności wojskowej w regionie dają szansę na zrównoważenie wzrostu Chin. Ponadto przewaga technologiczna i osiągnięcia rewolucji w dziedzinie wojskowości sprawiają, iż Siły Zbrojne USA wciąż mają przewagę nad armią ChRL. Amerykanie dominują dzięki potężnej marynarce wojennej, nowoczesnemu lotnictwu, maszynom bezzałogowym, pociskom manewrującym, systemom rozpoznawczym, infrastrukturze kosmicznej oraz przewadze informacyjnej ${ }^{62}$.

Rozwiązaniem problemu Stanów Zjednoczonych związanego z chińską strategią A2/AD ma być koncepcja bitwy powietrzno-morskiej. Wymaga ona jednak opracowania oraz zaimplementowania nowych doktryn i założeń operacyjnych, a ponadto konieczne jest wprowadzenie zaawansowanych systemów bojowych. Proces ten ma już miejsce i w rzeczywistości jest kolejnym etapem Revolution in Military Affairs ${ }^{63}$. Dlatego też Siły Zbrojne USA są cały czas modernizowane, a do służby wprowadzane są nowe typy myśliwców, bombowców, lotniskowców, okrętów podwodnych. W tym momencie trwają już prace nad nowym bombowcem strategicznym (program „Long Range Strike-Bomber” - LRS-B), nowym lotniskowcem typu Gerald R. Ford, czy też nowym okrętem podwodnym (Ohio Replacement Submarine). Rozwijany jest także system C4ISR, zwiększając tym samym świadomość sytuacyjną ${ }^{64}$.

W ewentualnym starciu celem ataków USA byłyby przede wszystkim wyrzutnie rakiet antysatelitarnych, centra dowodzenia, kontroli i łączności, stacje radiolokacyjne, system A2/AD, lotniska oraz bazy okrętów podwodnych. Stany Zjednoczone na początku konfliktu będą raczej musiały wycofać swoje siły morskie i powietrzne poza zasięg chińskich wyrzutni, a następnie stopniowo

60 J. Bójko, G. Piwnicki, Mocarstwowa polityka Chin na morzach Azji Południowo -Wschodniej, [w:] Chiny supermocarstwem XXI wieku?, s. 122.

${ }^{61}$ E. Heginbotham, op. cit., s. 22.

62 M. Green, K. Hicks, M. Cancian, op. cit., s. 15.

63 Chodzi o tzw. trzecią strategię offsetową - The Third U.S. Offset Strategy (przyp. autora).

64 U.S. Navy Information Dominance, Roadmap 2013-2028, s. 15-21, http://www.defenseinnovationmarketplace.mil/resources/Information_Dominance_Roadmap_ March_2013.pdf (dostęp: 03.05.2016). 
niszczyć systemy rozpoznawcze i uderzeniowe Chin z daleka za pomocą rakiet, okrętów podwodnych oraz ataków cybernetycznych. Dopiero później, po stworzeniu luk w chińskiej obronie, mogłyby zbliżyć się lotniskowce. Stany Zjednoczone potrzebowałyby ogromnych sił, by móc w pełni kontrolować teatr działań.

Konflikt ten wydaje się być nierealny, co nie oznacza, iż nie ma ryzyka jego wybuchu. Oba państwa zapewne będą się starać go uniknąć, chociażby ze względów gospodarczych i finansowych. Czas gra na korzyść Chin, przy zachowaniu obecnych tendencji, państwo to prześcignie USA pod względem ekonomicznym, a co za tym idzie, także pod względem siły oddziaływania w Azji Wschodniej. Dlatego Pekinowi wojna jest niepotrzebna. Wydaje się, iż z kolei dla Stanów Zjednoczonych granica „bezpiecznego” konfliktu, w którym miałyby niemal stu procentową pewność zwycięstwa, została przekroczona i wojna $\mathrm{z}$ ChRL stała się już zbyt ryzykowna. Nie można jednak wykluczyć działań nieracjonalnych, czy też w pewnym sensie przypadkowych, które doprowadzą do wojny.

\section{Podsumowanie}

Stosunki między Pekinem a Waszyngtonem to bez wątpienia jeden z najważniejszych elementów współczesnego systemu międzynarodowego. Oba kraje mają ogromy wpływ na bieg polityki międzynarodowej i specyfika systemu międzynarodowego zależy i będzie zależeć od charakteru relacji między Chińską Republiką Ludową i Stanami Zjednoczonymi.

Wciąż rosnące znaczenie Chin, zarówno pod względem ekonomicznym, politycznym jak i militarnym, kieruje oba państwa w stronę rywalizacji i konfrontacji. Jeśli ChRL chce odzyskać pozycję, jaką uważa za jej należną, to musi „wypchnąć” Stany Zjednoczone z regionu Azji Wschodniej i zachodniego Pacyfiku. Nie oznacza to, iż konflikt zbrojny między oboma państwami jest nieuchronny. Zarówno Pekin, jak i Waszyngton preferują politykę dialogu niż konfrontacji. Stany Zjednoczone wolałyby mieć w Chinach stabilnego partnera i czerpać korzyści z rozwoju ekonomicznego Azji Wschodniej. Dla Państwa Środka wojna niesie ogromne ryzyko utracenia tego, co już udało się osiągnąć. Wynik ewentualnego starcia dla obu stron jest trudny do przewidzenia, a zatem ryzykowny i kosztowny. Wojna między oboma państwami jest tym samym mało prawdopodobna. Ponadto łączą je silne więzy handlowe, a wręcz uzależnienie gospodarcze. Niemniej jednak należy spodziewać się, że Chiny będą starać się realizować zakładane cele i wypierać USA z regionu, lecz raczej poprzez wykorzystywanie metod asymetrycznych, stosując się do zasad Sun Tzu, by wygrać bez jednego wystrzału. 


\section{Bibliografia}

A FREEDOM of Navigation Primer for the Spratly Island, „Asia Maritime Transparency Initiative", 02.11.2015, http://amti.csis.org/fonops-primer/. AIR-SEA Battle. Service Collaboration to Address Anti-Access \& Area Denial Challenges, Air-Sea Battle Office 2013, http://archive.defense.gov/pubs/ ASB-ConceptImplementation-Summary-May-2013.pdf.

BALLISTIC Missile Defense Posture Review, Department of Defense, Washington 2010, http://archive.defense.gov/bmdr/docs/BMDR\%20as\%20 of\%2026JAN10\%200630_for\%20web.pdf.

BLICHARZ A., Chiny wzmocnity sporne wyspy na Morzu Poludniowochińskim, „Nowa Strategia” 18.02.2016, http://www.nowastrategia.org.pl/chiny-wzmocnily-sporne-wyspy-na-morzu-poludniowochinskim/.

CAMERON D., U.S. Clears Weapons Sale to Taiwan, „The Wall Street Journal", 16.12.2015, http://www.wsj.com/articles/u-s-clears-weapons-sale-to -taiwan-1450291541.

CAMPBELL K., ANDREWS B., Explaining the US 'Pivot' to Asia, „Americas” 2013, nr 1, https://www.coursehero.com/file/21690284/Explaining-the -US-Pivot-to-Asiapdf/.

CHHATWAL R. S., Stealth fighter: challenges for Indian Air Forces, Centre for Air Power Studies 2015, http://capsindia.org/files/documents/CAPS_Infocus_RS_12.pdf.

CHINY oficjalnie strasza USA wojna, „Niezależna”, 31.10.2015, http://niezalezna.pl/72489-chiny-oficjalnie-strasza-usa-wojna.

CLINTON H., America's Pacific Century, „Foreign Policy”, 11.10.2011, http:// foreignpolicy.com/2011/10/11/americas-pacific-century/.

CZULDA R., Rakiety przeciwlotnicze blokuja dostęp do spornych wysp. Chińska strategia w praktyce, „Defence24”, 17.02.2016, http://www.defence24. pl/309703,rakiety-przeciwlotnicze-blokuja-dostep-do-spornych-wyspchinska-strategia-w-praktyce.

DEFENSE Strategic Guidance, Department of Defense USA, Washington 2012, http://archive.defense.gov/news/Defense_Strategic_Guidance.pdf.

GLASER B., Pivot to Asia: Prepare for Unintended Consequences, [w:] Global Forecast 2012, C. Cohen, J. Gabel (red.), Center for Strategic \& International Studies, Washington 2012, https://csis-prod.s3.amazonaws.com/ s3fs-public/legacy_files/files/publication/120413_gf_green.pdf.

GREEN M., HICKS K., CANCIAN M., Asia-Pacific Rebalance 2025. Capabilities, Presence, and Partnerships. An Independent Review of U.S. Defense Strategy in the Asia-Pacific, Washington 2016, https://csis-prod. 
s3.amazonaws.com/s3fs-public/legacy_files/files/publication/160119_ Green_AsiaPacificRebalance2025_Web_0.pdf.

GREEN M., Rethinking U.S. Military Presence in Asia and the Pacific, [w:] Global Forecast 2012, C. Cohen, J. Gabel (red.), Washington 2012, https://csis-prod.s3.amazonaws.com/s3fs-public/legacy_files/files/publication/120413_gf_green.pdf.

HALIŻAK E., Polityka i strategia Chin $w$ kształtowaniu międzynarodowego bezpieczeństwa, seria: „Żurawia Papers”, zeszyt 10, Warszawa 2008.

HEGINBOTHAM E., The U.S.-China Military Scorecard Forces, Geography, and the Evolving Balance of Power, 1996-2017, Santa Monica 2015, http:// www.rand.org/content/dam/rand/pubs/research_reports/RR300/RR392/ RAND_RR392.pdf.

KOSTRZEWA M., Strategic Reassurance. Nowa koncepcja czy słabość polityki USA wobec Chin?, „Kwartalnik Kolegium Ekonomiczno-Społecznego. Studia i Prace", Warszawa 2011.

MARANTIDOU V., Revisiting China's 'String of Pearls' Strategy: Places 'with Chinese Characteristics' and their Security Implications, „Issues \& Insights” 2014, $\mathrm{nr}$ 7, https://csis-prod.s3.amazonaws.com/s3fs-public/legacy_files/ files/publication/140624_issuesinsights_vol14no7.pdf.

MARSZAŁEK-KAWA J. (red.), Chińska polityka zagraniczna i jej uwarunkowania, Wydawnictwo Adam Marszałek, Toruń 2008.

MARSZAŁEK-KAWA J. (red.), Chiny supermocarstwem XXI wieku? Rozważania na temat polityki i gospodarki Państwa Środka, Torun 2010.

MARSZAŁEK-KAWA J. (red.), Globalna potega Chin. Czynniki i perspekty$w y$, Toruń 2014.

NATIONAL Security Strategy, Washington 2015, https://obamawhitehouse. archives.gov/sites/default/files/docs/2015_national_security_strategy. pdf.

THE National Military Strategy of the United States of America 2015, Joint Chiefs of Staff, http://www.jcs.mil/Portals/36/Documents/Publications/2015_National_Military_Strategy.pdf.

NUCLEAR Posture Review Report, Department of Defense, Washington 2010, https://www.defense.gov/Portals/1/features/defenseReviews/ NPR/2010_Nuclear_Posture_Review_Report.pdf.

PIETRASIAK M., MIERZEJEWSKI D. (red.), Chiny w stosunkach międzynarodowych, Łódź 2012.

QADIR L., The United States and India Sign a 10-Year Defense Agreement and Set the Stage for Increased Defense Cooperation, „Global Public Policy and Government Affairs”, 11.06.2015, https://www.globalpolicywatch. 
com/2015/06/the-united-states-and-india-sign-a-10-year-defense-agreement-and-set-the-stage-for-increased-defense-cooperation/.

QUADRENNIAL Defense Review, Department of Defense, Washington 2014, http://archive.defense.gov/pubs/2014_Quadrennial_Defense_Review.pdf.

SEUL odpowiada Chinom. Rozszerza strefe obrony powietrznej, tvn24.pl, 29.11.2013, http://www.tvn24.pl/wiadomosci-ze-swiata,2/seul-odpowiada-chinom-rozszerza-strefe-obrony-powietrznej,375577.html.

TOMASZEWSKI J., Traktatowi sojusznicy USA w regionie Azji i Pacyfiku, „Bezpieczeństwo Narodowe” 2013, nr 25.

TOMASZEWSKI J., Zmiany w polityce bezpieczeństwa USA, „Bezpieczeństwo Narodowe" 2012, nr 23-24.

U.S. Navy Information Dominance, Roadmap 2013-2028, U.S. Navy Information Warfare Community, http://www.defenseinnovationmarketplace. mil/resources/Information_Dominance_Roadmap_March_2013.pdf.

ZAWADZKI M., Prezydent USA objeżdża Azję. Obama zaczą od uspokajania Japonii, wyborcza.pl, 25.04.2014, http://wyborcza.pl/1,76842,15852929,Prezydent_USA_objezdza_Azje__Obama_zaczal_od_uspokajania.html \#ixzz4862jfKtc.

ZBYTEK D., Azjatycka szachownica. Ameryka, Chiny, Indie, Pakistan, „Sprawy Polityczne", Warszawa 2008. 